\title{
Improving Community Performance by Re-examining Public Schools ${ }^{1}$
}

\author{
Randall A. Cantrell ${ }^{2}$
}

\section{Quick Facts}

- Two-thirds of U.S. students report that school violence is a concern for them (Garcia, 2003).

- The majority of students (54\%) attending schools that take preventive actions to reduce deviant behavior indicate that they feel safer in school as a result (Garcia, 2003).

\section{Terms to Help You Get Started}

Community: The neighborhoods, public schools, and public services found in a specific area

Overall community performance: How well neighborhoods, public schools, and public services address citizens' needs and desires

Supplemental programs: Activities sanctioned by schools that occur during non-instructional hours

Outreach activities: Programs intended to increase the public's involvement in schools

\section{Keywords}

Community performance, citizen behaviors, neighborhoods, public schools, public service

\section{Introduction}

This series of EDIS publications introduces readers to the concept of overall community performance and suggests minor modifications to neighborhoods, public schools, and public services that could help citizens improve their communities. This publication is for a general audience and provides a list of changes to public schools that, if enacted, may help improve a community's performance. The other three publications in this series include the following:

- Improving Community Performance by Re-examining the Neighborhood (http://edis.ifas.ufl.edu/fy1372)

- Improving Community Performance by Re-examining Public Services (http://edis.ifas.ufl.edu/fy1373)

- Improving Savings, Health, and Happiness by Making Small Modifications to Your Community (for an academic audience) (http://edis.ifas.ufl.edu/fy1371)

\section{How Behavioral Policies in Public Schools May Affect Students}

A fifth-grade student was playing on the playground during recess when a smaller student slapped him for no apparent reason. The victim had been taught that all infractions were to be reported to school authorities. He defended himself during a previous event, and he promised afterward to

1. This document is FCS3317, one of a series of the Department of Family, Youth and Community Sciences, Florida Cooperative Extension Service, Institute of Food and Agricultural Sciences, University of Florida. First published May 2013. Please visit the EDIS website at http://edis.ifas.ufl.edu.

2. Randall A. Cantrell, assistant professor, Department of Family, Youth and Community Sciences; Florida Cooperative Extension Service, Institute of Food and Agricultural Sciences, University of Florida, Gainesville, FL 32611.

This material was prepared with the support of the University of Florida. However, any opinions, findings, conclusions, or recommendations expressed are those of the author(s) and do not necessarily reflect the views of the University of Florida. 
comply with the school policy. He reported the student who slapped him to the school authorities, and the assailant was paddled three times. The incident was presumably over.

Seven years later, the same student victimized as a fifth grader was on the high school football team and attended a party with his girlfriend. The same boy who slapped the student was also at the party. The assailant had been drinking alcohol and walked up to the victim's girlfriend and said, "I slapped your big, tough boyfriend in the face back in fifth grade, and he went crying to the principal." The victim found himself in the same situation as before. However, this time no school administrators could intervene; there were only teenagers, and some of them were intoxicated. Fortunately, the victim and his girlfriend left without incident. The boy assaulted - who is a father today - continues to think about school policies now that he has children of his own.

This story is one anecdotal example of how school policies may affect the community and may have future implications for the community's overall performance. However, in this study, it was found that the modifications to public schools did not represent a statistically significant category, and may show disconnect between the public and public school systems, which may need further research.

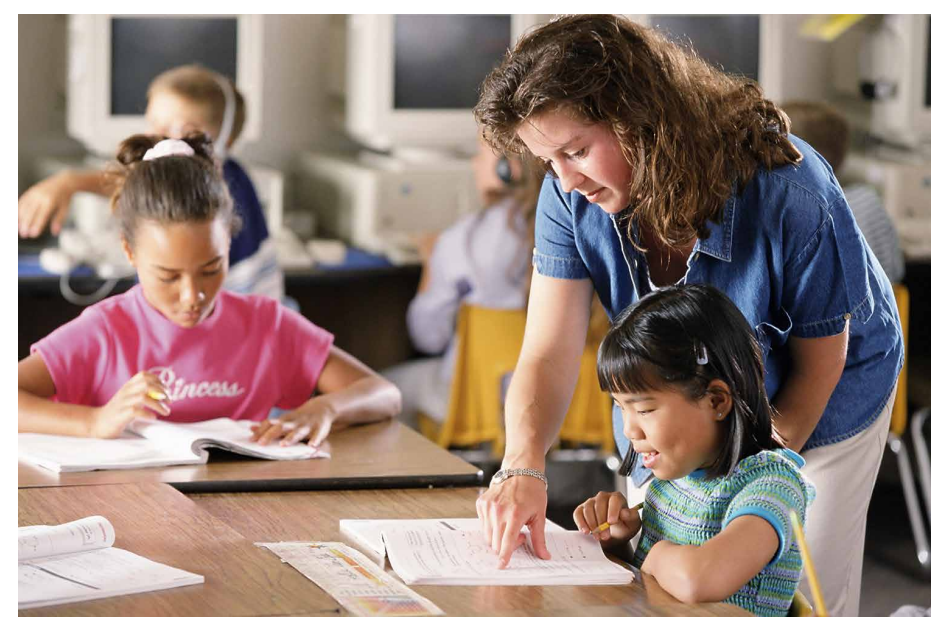

Figure 1. School policies can have an effect on the community, and making modifications to them may help to improve the community's performance.

Credits: Brand X Pictures

\section{How Might Your Family Benefit by Improving Overall Community Performance?}

The concept of overall community performance has much to do with re-thinking how people can be happier, which is not necessarily the same as being comfortable. Finding ways for students to share the same learning environment in a relatively peaceful state is not an easy task. Reaching agreements rather than spending time resolving conflicts is an attainable goal and one worthy of pursuit. If citizens focus on the various factors comprising their overall community performance, people in the community may be able to save time and money and also strengthen the neighborhood and community. However, improving overall community performance sometimes takes place in small increments and often requires time before results are noticeable.

\section{How Are School Considerations Chosen to Improve Overall Community Performance?}

Respondents from a representative sample in the United States were asked to rate multiple items-as identified in the literature - that could improve overall community performance (Cantrell \& Stafford, 2013). The goal was to determine which of 81 items the respondents thought had the greatest likelihood of improving their community's overall performance. The public school considerations were categorically found to be statistically non-significant factors for increasing overall community performance, but many of the listed items represent important considerations for homebuyers in most communities.

\section{School Considerations That Nominally Impact Community \\ Improvement}

List 1 shows the public school considerations sample participants felt would have little to no improvement on overall community performance.

\section{List 1. Public School Considerations with Little to No Impact on Overall Community Improvement}

- Children attending a school located within 20 minutes driving time from home

- Having better maintained schools (inside and outside)

- Having better policed/monitored schools

- Having security cameras located on all school property, including buses

- Having more enforceable programs that separate unmotivated students from motivated students

- Having more stringent and enforceable dress codes 
- Having more stringent and enforceable student codes of conduct

- Having regularly scheduled time for citizens to meet with school administrators

- Planning programs that reward parents for visiting classrooms after receiving permission

- Planning programs that reward citizens for volunteering as after-school tutors

- Planning programs that reward schools for hosting industry partners in the school

- Planning programs that reward citizens for judging science fair projects

- Planning programs that reward schools for sponsoring events that bring students and citizens together

- Having (or improving) a foreign student-exchange program

- Enabling and allowing all classrooms to access the Internet

- Having programs that enable students to learn lessons from reformed juvenile delinquents

- Having programs that enable students to learn lessons from recent college graduates

- Having programs that reward students for attending classes on Saturday morning

- Offering onsite after-school programs to supervise students until parents pick them up

- Having required quiet stretching time for all students in the school

- Having required quiet stretching time for all adults in the school

- Dedicating at least 30 minutes for all students and adults in the school to eat lunch

- Requiring all students to perform community service

- Not allowing "junk food" or soda vending machines on school property

- Allowing citizens to use the athletic facilities when not in use

- Having achieving students receive more acknowledgement in the community

- Having achieving teachers and administrators receive more acknowledgement in the community

\section{Summary}

As previously mentioned, in this study's survey, the public school considerations did not represent a statistically significant category. The study only measured the items for public schools and not private ones, which may have affected the results. It seems counterintuitive for citizens (especially with minors residing in the home) to not believe that improvement in the public school items measured could potentially improve the overall performance of their community.

One explanation may be that citizens and public school systems have grown more disconnected as performance requirements have become more stringent in public schools. Many public schools have become complex and are difficult to comprehend without actively pursuing information about their mandates and agendas. Citizens may find it easier to simply trust that elected officials are employing tax dollars in a manner effective and consistent with the students' and community's needs. Research should be conducted to further examine whether the citizens' trust is well-earned by public school systems. Successful business models are based on understanding what paying customers desire and then making certain that paying customers understand they are receiving what they desire. One way to consider tax-paying citizens is as paying customers of public school systems, and they have a right and responsibility to ensure that they are receiving the services and outcomes desired.

\section{References}

Cantrell, R., \& Stafford, A. (2013). The introduction and development of the community-flow measurement instrument. Journal of Community Development. doi:10.1080/155 75330.2012 .761640

Garcia, C.A. (2003). School safety technology in America: Current use and perceived effectiveness. Criminal Justice Policy Review 14(1), 30-54. 